\title{
Squamous Cell Carcinoma in Chinese Hamsters (Cricetulus griseus)
}

\author{
Alexsandro Machado Conceição', Rachel Livingstone Felizola Soares de Andrade', \\ Carlos Alberto Palmeira Sarmento' ${ }^{1}$ Karine dos Santos Souza ${ }^{2}$ \& Emerson Ticona Fioretto ${ }^{3}$
}

\begin{abstract}
Background: The companion animal market has changed over the years. The number of people living in small apartments has increased; as a result, the demand for small pets such as exotics, fish, and small rodents has also increased due to their smaller space requirements and ease of handling and care. Pets help relieve anxiety and stress in people suffering from social issues. Small rodents are usually bred in specific cages with cellulose or wood shaving bedding, and fed with commercially available diets. Small rodent clinics struggle due to the lack of scientific reports on some diseases and therapies. To date, the oncology literature is too limited to develop better diagnosis and treatment methods. Here, we report three cases of squamous cell carcinoma in the mandibular region of Chinese hamsters (Cricetulus griseus).

Case: Three adult male hamsters averaging 1.5 years old, from different pet stores, bred under home conditions by different owners in Sergipe, Brazil, were brought to the Dr. Vicente Borelli Hospital at Pio X University for exotic veterinary care. Each animal had been bred alone in a specific breeding cage. Each had a history of apathy, loss of appetite, and rapid deformity of the facial region. Radiographs showed areas of bone involvement and extensive injury, with partial resorption of the left ramus and angle of the mandibular region. Due to the location of the tumor mass, the clinical status, and limitations in systemic treatment, euthanasia was recommended for each animal. After anamnesis, the animals were subjected to clinical assessment. A firm and well-circumscribed mass was identified on palpation. In case A, it compromised the left mandible from the angle to the body and extended to the maxillary soft tissues and left superior lips. In case $\mathrm{B}$, it extended from the ramus to the symphysis on the left side and to the maxillary region, similar to case A. In case C, it extended on both sides of the mandible symphysis, with no alterations in the maxillary soft tissues. Following clinical examination, each animal underwent laterolateral and dorsoventral radiographic examination; no images were suggestive of pulmonary metastasis. However, an expansive mandibular lesion with partial resorption, suggestive of bone neoplasia, was detected. The animals were dehydrated and in clinical distress, and euthanasia was recommended. Histopathological examination of samples from the tumor sites revealed moderate cellular and nuclear pleomorphism and proliferation of neoplastic keratinocytes, suggestive of squamous cell carcinoma, a malignant tumor of epidermal keratinocytes with a highly invasive and aggressive nature.

Discussion: The number of reports in the literature of cancer in small rodent companion animals has lead us to believe that neoplasms in these animals are misdiagnosed and/or that their prevalence is underreported. The literature describes that the tumor incidence in hamsters is $3-40 \%$, and that the incidence is higher in male rodents. This incidence range increases the analysis of cancer in these animals from rare to middle-frequent what do not contribute to the animals' clinics and to small rodent therapeutics. Differential diagnosis of squamous cell carcinoma and other tumor types should be addressed, especially osteosarcomas. Histopathological examination is essential to clarify the etiopathogenesis.
\end{abstract}

Keywords: rodents, neoplasm, keratinocytes. 


\section{INTRODUCTION}

The demand for SRs companion animals has increased in previous years. For potential owners, the appealing characteristics of small rodents include the low cost of breeding and the minimal spatial requirements. However, small rodent owners often neglect their pets' health care and usually do not obtain veterinary consultation for pathologies due to the animals' short life expectancy. Meanwhile, neoplasms have been commonly reported in hamsters [4,5].

Carcinogenesis is a dynamic process that consists of malignant neoplasm development from the earliest changes at the molecular level to the formation of a highly invasive and aggressive tumor that can destroy the host organism, generating various symptoms in animals. Changes are related to oncogenesis activation or the inactivation of tumor suppressor genes, which interferes with cell genome stability, proliferation, differentiation, and apoptosis [8].

Squamous cell carcinoma (SCC) is a malignant tumor of epidermal keratinocytes $[3,10,12]$, commonly reported in tropical countries such as Brazil. Ultraviolet light, lack of epidermal pigments, hair loss, poor hygiene, and genetic factors are the most commonly associated causes. It can affect companion or production animals at a young age, and the incidence increases with age [15]. The object of the present study was to report three cases of squamous cell carcinoma in Chinese hamsters (Cricetulus griseus) treated at the Dr. Vicente Borelli Veterinary Hospital, Aracaju, SE, Brazil.

\section{CASES}

From 2013-2016, 78 small rodents received treatment at the Dr. Vicente Borelli Hospital. Among them, 3 cases of squamous carcinoma were diagnosed. All cases were adult males, with an average age of 1.5 years. In each case, the animal was bred alone in a specific breeding cage. One animal was fed a seed ration, and the other two cases received a ration extruded for rodents. The common presenting complaint was the presence of a rapidly evolving deformity of the face and progressive loss of appetite. In the first case, on clinical examination, a fixed ulcerative lesion and a firm volume increase were seen in the left mandibular region, involving and destroying the gingival border and lower lip, skin, and soft tissue of the mandible and maxilla (Figure 1A).
The other two cases demonstrated moderate dehydration and similar neoformation and increase in volume in the mandibular region. On palpation, a firm, well-circumscribed mass was identified in both cases (Figure $1 \mathrm{~B} \& \mathrm{C}$ ). In all cases, laterolateral and dorsoventral radiographs revealed areas with increased volume and soft tissue density with bone involvement, characterized by solar blast and expansive mandibular lesion with partial resorption, suggestive of bone neoplasia (Figure $1 \mathrm{D} \& \mathrm{E}$ ). No images suggestive of pulmonary metastasis were found, but euthanasia was suggested due to tumor extension, location, clinical status, and limitations of systemic treatments; tumor samples were obtained for histopathologic examination (Figure 1F).

Tissue samples from all three animals were collected and stored in $10 \%$ formalin in sterile tubes, labeled, and sent to the Laboratory of Morphophysiological and Molecular Analysis at the Federal University of Sergipe for analysis. Samples were processed using standard paraffin embedding ${ }^{1}$ and $5 \mu \mathrm{m}$-thick transverse sections were made using a Leica ${ }^{2}$ rotational microtome, mounted in regular slides and stained in Hematoxylin-Eosin ${ }^{1}$ according to standard procedure. Microphotographs were obtained using a standard light microscope Leica ${ }^{2}$ DM50 and a Leica ${ }^{2}$ Application Suite software for acquisition and image analysis

Histopathological examination demonstrated proliferation of well-differentiated squamous epithelial cells, moderate cellular and nuclear pleomorphism with vesicles in the nuclei, evident double nucleoli, and moderately eosinophilic cytoplasm. Cells were arranged concentrically in nests of varying sizes, and centrally presented intense formation of "keratin pearls". Additionally, we observed keratinization of neoplastic cells and moderate fibrovascular stroma. Neoplastic cells were adhered to the periosteum and mingled with bone spicules (Figure $2 \&$ D). Histopathological findings suggested a well-differentiated squamous cell carcinoma (Figure $2 \mathrm{~B} \& \mathrm{C}$ ).

\section{DISCUSSION}

Tumor incidence in hamsters varies in the literature, ranging from $3-40 \%$; the incidence in males is higher. Advances in diagnostic methods have increased its detection in recent decades $[1,13,14]$.

Similar reports have described frequent signs in these animals, such as apathy, loss of appetite, facial deformity, and excessive salivation [11]. The occur- 

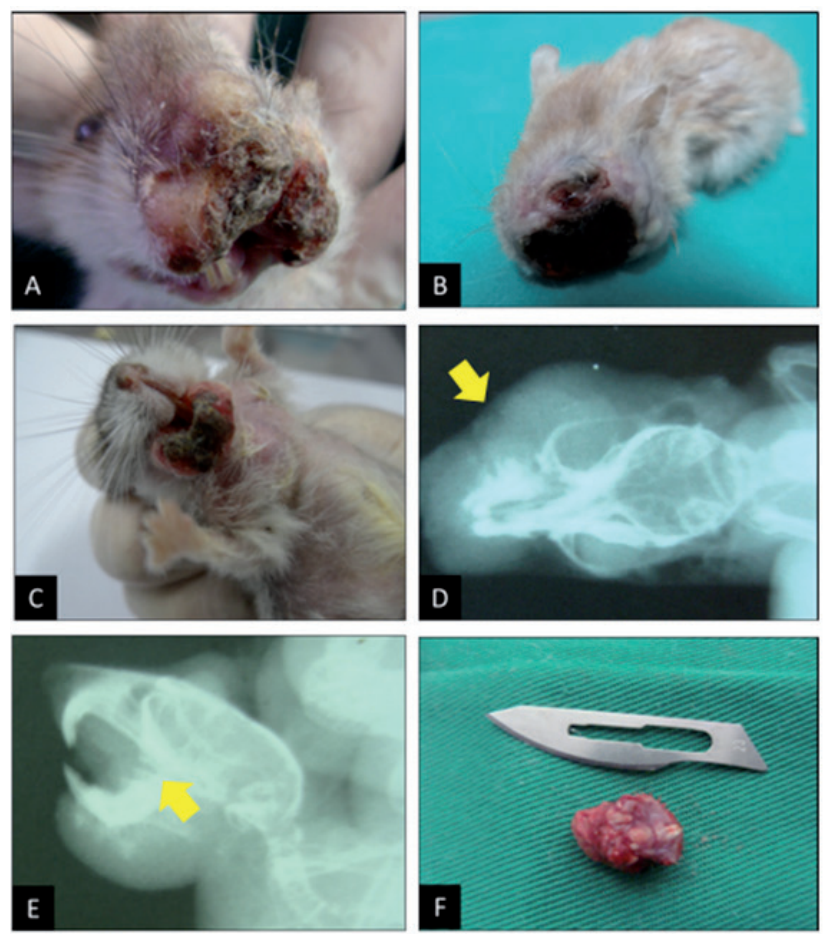

Figure 1. A- Firm, well-circumscribed tumor mass in the mandibular region. B- Deformity of the gingival border, lower lip, skin, and soft parts of the mandible and maxilla. C- Firm, well-circumscribed aspect of a mandibular neoformation. D- Skull dorsoventral radiograph revealing a radiolucent region (arrow) in the mandible, suggesting bone lysis. E- Skull laterolateral radiograph revealing a radiolucent region (arrow) in the mandible suggesting bone lysis. F- Tumor mass with the presence of incisors, indicating the extension of the lesion.

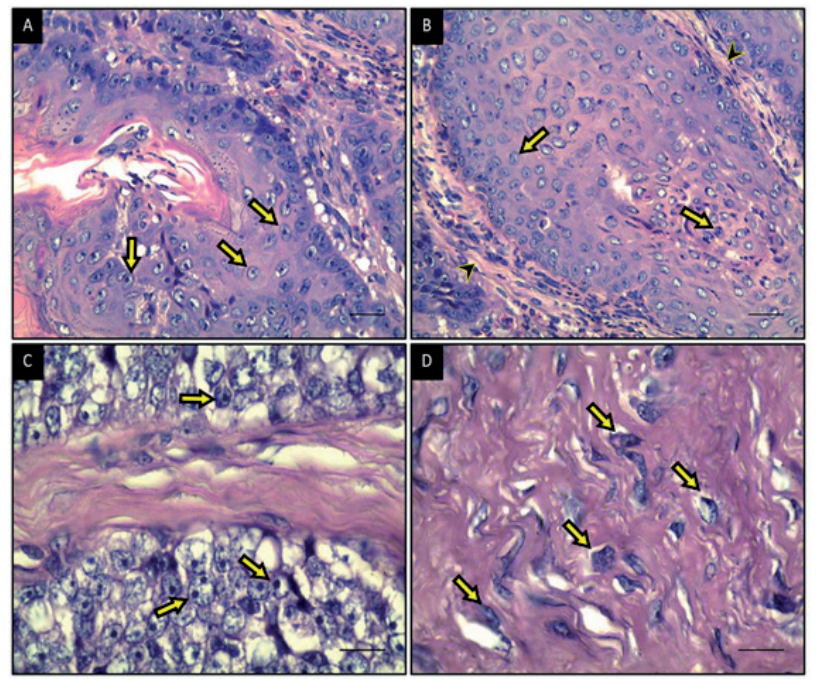

Figure 2. Photomicrograph of invasive neoplasia in a Chinese hamster. A- N neoplastic cells (arrows) scattered along the tissue. B- Arrangement of neoplastic cells (arrows) and invasiveness on adjacent peripheral tissues (arrowhead). C- Cells with evident nucleoli (arrows), indicating mitotic process. D- Invasion of neoplastic cells (arrows) and disorganization of adjacent tissue. Hematoxylin and eosin stain [Scale bar A \& B $=30 \mu \mathrm{m}$; $\mathrm{C} \& \mathrm{D}=15 \mu \mathrm{m}]$.

rence of carcinomas in the oral cavity is extremely rare in Chinese hamsters [7]; moreover, spontaneous neoplasms in domestic hamsters are rarely reported [6].
Therefore, their low prevalence might be associated with owners avoiding veterinary assistance or with a lack of clinical reports by veterinarians. Although various types of neoplasms have been reported, the most important are hemangioma, lymphosarcoma, fibrosarcoma, and basal cell carcinoma; the most malignant neoplasm is lymphosarcoma, which may have a viral etiology [13]. The oral cavity of Chinese hamsters has well-developed cheek pouches to store food, which are characterized by a thin epithelial membrane [2]. This anatomic characteristic might be involved in the susceptibility to neoplasm development and should be investigated further.

Stabenow et al. [13] described a similar case in a Campbell's hamster (Phodopus campbelli); a tumor of the submandibular region had invaded the bone tissue. Conversely, Montenegro \& Franco [9] reported a case of squamous cell carcinoma of the nasal epithelium with no bone involvement. Kondo et al. [6] reported an analysis of 85 domestic hamsters with tumor lesions; squamous cell carcinoma was the second most common epithelial neoplasm; papilloma was the most common in both male and female animals 1-2 years of age affected by squamous cell carcinoma. The most commonly affected anatomical sites were the head, neck, and abdomen. Despite the small number of animals in the present study, their age, site of invasion, and clinical signs are similar to previous reports [6].

It is believed that the actual prevalence of neoplasms in these animals is underreported due to owner negligence in seeking medical attention when the hamster develops early signs of the disease. Additionally, we emphasize the importance of differential diagnosis of squamous cell carcinoma and other tumor types, especially osteosarcomas. Therefore, histopathological diagnosis is essential to clarify the etiopathogenesis. This fact highlights the importance of reporting spontaneous neoplastic diseases in these animals and other captive small rodents to support prognostic and therapeutic investigations in this area.

\section{MANUFACTURERS}

${ }^{1}$ Synth Acessórios e Equipamentos para Laboratório. Diadema, SP, Brazil.

${ }^{2}$ Leica Microsystem. Wetzlar, Germany.

Declaration of interest. The authors report no conflicts of interest. The authors alone are responsible for the content and writing of this paper. 


\section{REFERENCES}

1 Alencar N.X., Correia I.S., Romão M.A.M.P., Viera T.B., Ferreira M.L.G. \& Tortelly R. 2003. Osteossarcoma de tecidos moles em hamster chinês (Cricetulus griseus): relato de caso. In: Anais do VII Congresso e XII Encontro da ABRAVAS (São Pedro, SP). p.86.

2 Bennett R.A. \& Mullen H.S. 2004. Soft tissue surgery. In: Quesenberry K.E. \& Carpenter J.W. (Eds). Ferrets, rabbits, and rodents. Clinical Medicine and Surgery. 3rd edn. St. Louis: Saunders, pp.324-330.

3 Goldschimidt M.H. \& Hendrick M.J. Tumors of the skin and soft tissues. In: Meuten D. J. (Ed). Tumors in domestic animals. 4th edn. Ames: Iowa State Press, pp.45-118.

4 Harkness J.E. \& Wagner J.E. 1995. Neoplasia in the hamster. In: Harkness J.E. \& Wagner J.E. (Eds). The Biology and Medicine of Rabbits and Rodents. 4th edn. Philadelphia: Williams \& Wilkins, pp. 254-255.

5 Homburger F. 1983. Background data tumor incidence in control animals (Syrian hamsters). Progress in Experimental Tumor Research. 26(5): 259-265.

6 Kondo H., Onuma M., Shibuya H. \& Sato T. 2008. Spontaneous tumors in domestic hamsters. Veterinary Pathology. 45(5): 674-680.

7 Martorell J., Fondevila D. \& Ramis A.S. 2005. Spontaneous squamous cell carcinoma of the cheek pouch in two dwarf hamsters (Phodopus sungorus). Veterinary Records. 156 (14): 650-651.

8 Montenegro M.R. \& Franco M. 2008. Patologia: Processos gerais. 4.ed. São Paulo: Atheneu, 320p.

9 Rosolem M.C., Romero D.C., Rozza D.B., Souza N.C. \& Simões D.C. 2012. Carcinoma de células escamosas em epitélio nasal de um hamster chinês - Relato de caso. PUBVET. 6(19): 1375-1380.

10 Scopel D., Spader M.B., Guim T.N., Danielli V.M. \& Fernandes C.G. 2007. Estudo retrospectivo da casuística de carcinoma de células escamosas em felinos, bovinos, caninos, eqüinos e ovinos entre os anos de 2002 e 2006 no Laboratório Regional de Diagnóstico da Universidade Federal de Pelotas. In: Anais do Congresso de Iniciação Científica de Pesquisa e Responsabilidade Ambiental (Pelotas, Brazil). p.4.

11 Selk-Ghaffari M., Moay R.F. \& Dezfoulian O. 2009. Spontaneous differentiated squamous cell carcinoma of cheek pouch in a Syrian hamster. Iranian Journal of Veterinary Research. 10(1): 84-86.

12 Souza R.P., Tornin O.S., Paes Jr. A.J.O. \& Gonzalez F.M. 2005. Carcinoma espinocelular do conduto auditivo externo: estudo por tomografia computadorizada de seis casos. Radiologia Brasileira. 38(3): 181-185.

13 Stabenow C.S., Oliveira F.C.R., Santos A.S.O. \& Carvalho E.C.Q. 2006. Carcinoma de células escamosas em hamster de criação doméstica. Revista Universidade Rural: Série Ciências da Vida Seropédica. 26: 7-8.

14 Werner P.R., Chiquito M. \& Pachaly J.R. 1998. Estudo retrospectivo das neoplasias diagnosticadas em animais selvagens ou exóticos pelo serviço de patologia do Hospital Veterinário da Universidade Federal do Paraná entre 1974 e 2006. Archives of Veterinary Science. 3(1): 39-44.

15 Xavier S.D., Bussoloti I.F. \& Lancellotti C.L.P. 2005. Prevalência de achados sugestivos de papilomavírus humano (HPV) em biópsias de carcinoma espinocelular de cavidade oral e orofaringe: estudo preliminar. Revista Brasileira de Otorrinolaringologia. 71(4): 510-514. 